\title{
De opinierichtingen in de Belgische dagbladpers
}

door Theo LUYKX

Cewoon Hoogleraar aan de Rijksuniversiteit te Gent.

\section{$\star$}

De Belgische pers was van bij haar ontstaan overwegend een opiniepers. De conservatief-katholieke en de liberaal-burgerlijke pers dateren echter reeds van vóór het ontstaan van de gelijkdenkende partijen. Reeds sedert de doorbraak van de Nieuwe Denkbeelden op het einde van de $18 \mathrm{e}$ eeuw werd immers door privé-initiatief een katholieke en liberale pers op de markt gebracht, waar de liberale partij slechts dateert van 1846 en de katholieke van 1884. Dit is wellicht de hoofdoorzaak dat de katholieke partij (CVP sedert 1945) en de liberale partij (PVV sedert 1961 ), in tegenstelling met de socialistische partij, nog steeds over geen uitgesproken partijorganen beschikken. Alleen de merkelijke jongere christelijke arbeidersbeweging, die sedert de late $19 \mathrm{e}$ eeuw opkwam, bezit zowel in Vlaanderen als in Wallonië een eigen dagbladpers, namelijk Het Volk en La Cité. Het is in dit verband trouwens geen toeval dat Het Volk in het jaar van Rerum Novarum (1891) werd opgericht.

De zogezegde linkse partijen, de socialistische en de communistische, kwamen tot stand op een ogenblik dat de goedkope massapers reeds haar intrede had gedaan. Van bij hun stichting hebben zij zich dan ook onmiddellijk ingespannen om door middel van een goedkoop massablad, dat meteen als partijorgaan zou optreden, hun invloed bij de volksmassa uit te breiden. De Gentse Vooruit, officieel orgaan van de Gentse socialistische federatie, dateert immers van 1884 en de Brusselse Le Peuple, officieel orgaan van de BSP, van 1885 . Hetzelfde gebeurde met de communistische partij : bij haar stichting in 1921 lanceerde zij onmiddellik het partijblad Le Drapeau Rouge.

Wat betreft de federalistische of zogezegde communautaire partijen, valt het op eerste gezicht op dat het VNV van vóór de oorlog steeds ove een partijkrant heeft beschikt - De Scbelde in 1919-1936 en Volk 
en Staat in 1936-1944 - terwijl na de oorlog, noch de Volksunie, noch het Rassemblement Wallon of het Brusselse Front des Francophones, eigen partij-organen bezitten. Dit kan wel enigszins verband houden met het feit dat zij voldoende aan bod komen in sommige bestaande dagbladpers, doch de hoofdoorzaak ligt elders. De periode van de nieuwe krantenstichtingen lijkt in onze democratische landen immers definitief afgesloten. De stichting van een nieuw dagblad vereist immers ontzaglijke investeringen, zodat de bestaande kranten gaan gelijken op " instituties ", die de krantenmarkt monopoliseren.

Naast de grote meerderheid van kranten, die, met uitzondering van de socialistische en communistische niet partijgebonden doch enkel ideologisch gericht zijn, bestaat in ons land ook een groep van vier zogezegde «neutrale " kranten. Deze «neutraliteit» komt hierop neer dat zij beweren voor geen enkele partij uitdrukkelijk te opteren. Voor het overige belet hen dat niet stelling te nemen in een groot aantal problemen, die het openbare leven beroeren. Het hoofdorgaan van deze zogezegde "neutrale groep » is de Brusselse Le Soir die zich kon meester maken van de Luikse La Meuse en de Brusselse beeldkrant La Lanterne. Opvallend is dat deze zogezegde «neutrale » pers tot Brussel en Wallonië beperkt is, terwijl de Vlaamse pers globaal ideologisch gebonden is.

Om een dieper inzicht te bekomen in de Belgische pers als uitdrukking van de verschillende politieke ideologiën in ons land, schetsen wij vooreerst de na-oorlogse evolutie van het aantal kranten per opinierichting, waaruit onder meer zeer duidelijk het na-oorlogse concentratieverschijnsel in de Belgische pers zal blijken. Wij gaan vervolgens even dieper in op de ideologische strekkingen die langs de Belgische dagbladpers aan het licht komen. Daarna trachten wij vast te stellen welke de werkelijke oplage is van de kranten per opiniegroep. In een laatste paragraaf vergelijken wij het aantal krantenlezers van een bepaalde opiniegroep met het aantal kiezers voor de gelijkdenkende politieke partij.

\section{Evolutie van het aantal titels per opinierichting.}

Op basis van de opinierichtingen, die de kranten zich zelf toekennen, kan men vijf groepen in de Belgische pers onderscheiden: de katholieke, de liberale, de socialistische, de communistische en de zogezegde neutrale of onafhankelijke. Binnen deze groepen bestaan echter nog schakeringen, die dikwijls verband houden met de sociale en ook de Belgische communautaire problemen. De katholieke pers bezat steeds meer dan de helft van de titels van de Belgische pers, doch bij haar 
waren de schakeringen op de genoemde vlakken ook het meest uitgesproken.

Indien wij voor de testjaren 1950,1960, 1970 en 1975 de titels van de kranten rangschikken volgens hun opinierichting, dan komt men tot volgende tabellen.

1. In 1950 (49 titels).

\begin{tabular}{|c|c|c|c|c|c|c|}
\hline & Katholiek & Socialist & Liberaal & Communist & Neutraal & Totaal \\
\hline Nederlandstalig & 14 & 2 & 2 & 1 & - & 19 \\
\hline Franstalig. & 11 & 6 & 6 & $i$ & 5 & 29 \\
\hline Duitstalig. . & 1 & - & - & - & - & 1 \\
\hline Totaal & 26 & 8 & 8 & 2 & 5 & 49 \\
\hline
\end{tabular}

Tussen 1950-1960 verdween de neutrale La Nation Belge en de communistische De Rode Vaan werd weekblad, zodat de situatie de valgende werd :

2. In 1960 (47 titels).

\begin{tabular}{l|c|c|c|c|c|c}
\hline & Katholiek & Socialist & Liberaal & Communist & Neutraal & Totaal \\
\hline Nederlandstalig & 14 & 2 & 2 & - & - & 18 \\
Franstalig. & 11 & 6 & 6 & 1 & 4 & 28 \\
Duitstalig . . & 1 & - & - & - & - & 1 \\
\hline Totaal . . . & 26 & 8 & 8 & 1 & 4 & 47
\end{tabular}

Tussen 1960-1970 verdwenen drie nederlandstalige katholieke kranten (De Gazet, Het Nieuws van den Dag en 't Vrije Volksblad) en een franstalig katholiek blad (Gazette de Liège). De communistische Le Drppeau Rouge werd weekblad, terwijl de liberale pers een titel bijkreeg door de oprichting van Le Progrès (plaatselijke editie van La Nouvelle Gazette) en de socialistische een titel verloor door de fusie van de Journal de Charleroi en Indépendance.

De situatie in 1970 werd aldus de volgende :

3. In 1970 ( 42 titels).

\begin{tabular}{|c|c|c|c|c|c|c|}
\hline & Katholiek & Socialist & Liberaal & Communist & Neutraal & Totaal \\
\hline $\begin{array}{l}\text { Nederlandstalig } \\
\text { Franstalig . . } \\
\text { Duitstalig . . }\end{array}$ & $\begin{array}{r}11 \\
10 \\
1\end{array}$ & $\begin{array}{r}2 \\
5 \\
-\end{array}$ & $\begin{array}{r}2 \\
7 \\
-\end{array}$ & - & $\begin{array}{r}- \\
-\end{array}$ & $\begin{array}{c}15 \\
26 \\
1\end{array}$ \\
\hline Totaal . . & 22 & 7 & 9 & 0 & 4 & 42 \\
\hline
\end{tabular}


Tussen 1970-1975 verdwenen de nog in Vlaanderen bestaande franstalige kranten, namelijk de liberale La Flandre Libérale en Le Matin, alsmede de katholieke La Métropole. De communistische Le Drapeau Rouge werd echter van weekblad opnieuw een dagblad, terwijl de Nieuwe Gids en de Antwerpse Gids hun titels versmolten, zodat de situatie sedert 1975 de volgende werd:

4. Sedert 1974 (39 titels).

\begin{tabular}{|c|c|c|c|c|c|c|}
\hline & Katholiek & Socialist & Liberaal & Communist & Neutraal & Totaal \\
\hline $\begin{array}{l}\text { Nederlandstalig } \\
\text { Franstalig }\end{array}$ & $\begin{array}{r}10 \\
9\end{array}$ & $\begin{array}{l}2 \\
5\end{array}$ & $\begin{array}{l}2 \\
5\end{array}$ & $\bar{i}$ & - & $\begin{array}{l}14 \\
24\end{array}$ \\
\hline $\begin{array}{l}\text { Franstalig . . } \\
\text { Duitstalig . }\end{array}$ & $\begin{array}{l}9 \\
1\end{array}$ & 5 & 5 & - & - & $\begin{array}{r}24 \\
1\end{array}$ \\
\hline Totaal & 20 & 7 & 7 & 1 & 4 & 39 \\
\hline
\end{tabular}

\section{De katholieke Opiniepers.}

Deze bezat steeds het grootste aantal titels ( 26 in 1950 en nog 20 in 1975 ) en tevens het grootste aantal lezers. Geen enkele van deze kranten kan voorgesteld worden als de officiële spreekbuis van de CVP-PSC. Wel valt het op dat in perioden, waarin de CVP een kartelregering vormt met de BSP vooral De Nieuwe Gids, die financieel afhankelijk is van het ACW, als officieuze spreekbuis fungeert van de CVP (bijvoorbeeld in de jaren 1961-1965 tijdens de regering Th. Lefèvre-Spaak). Naast De Nieuwe Gids vertoont Het Belang van Limburg wellicht de meeste neiging om zich met de CVP te vereenzelvigen. Deze niet-gebondenheid van de katholieke pers aan een politieke partij belet echter niet dat zij in verkiezingstijd, met min of meer ijver, de CVP-PSC steunt. Dit wordt trouwens vooral het geval als bij de verkiezingen belangrijke katholieke belangen op het spel staan, zoals bijvoorbeeld in 1958 bij de strijd rond de schoolwetgeving-Collard. (1) De schakeringen binnen de katholieke pers houden essentieel verband - zoals wij boven reeds schreven - met de sociale en Belgisch-communautaire problemen.

\section{De sociaal-conservatieve kranten.}

De meest uitgesproken sociaal-conservatieve krant is La Libre Belgique. $\mathrm{Zij}$ pleit tegen elke vorm van staatsdirigisme, zodat zij op sociaal-eco-

(1) Cf W. VAN DER BIESEN, De verkiezingspropaganda in de democratische maatschappij. Een literatur -kritische studie en een inhoudsanalyse van de (Belgische) verktezingscampagne van 1958 in de katholieke pers en in de propagandapublicaties van de CVP, in : Massacommunicatie, zomer 1973, pp. 205-224. 
nomisch vlak overhelt naar het economisch-liberalisme en affiniteiten bezit met het politiek liberalisme, vooral nadat de liberale partij in 1961 amgevormd werd tot de PVV-PLP, die haar anticlerikaal standpunt liet varen. De krant neemt dan ook een bijzonder kritische houding aan tধgenover de CVP-PSC, als deze partij regeert met de BSP.

Tot deze conservatieve richting, maar toch minder uitgesproken, behoort ook de groep van Le Rappel (Charleroi) met zijn twee regionale edities Le Journal de Mons en L'Echo du Centre (La Louvière). Twee katholieke kranten, die traditioneel ook een conservatieve koers vaarden, zijn ondertussen verdwenen: de oude La Gazette de Liège, die op 1 januari 1967 opgeslorpt werd door de leidinggevende conservatieve krant La Libre Belgique en La Métropole (Antwerpen), die sedert oktober 1966 toebehoorde aan de krantengroep-Rossel en reeds veel van haar individualiteit had verloren; zij verdween definitief op 30 juni 1974.

\section{Christendemocratische kranten.}

De meest verspreide krant in deze richting is Het Volk (Gent). Zij werd opgericht in het jaar van «Rerum Novarum » (1891) en bleef sedertdien trouw aan haar oorsprong. Tegenover de Vlaamse emancipatie heeft zij, vooral sedert 1929 (standpuntsverklaring van het ACW ten voordele van het regionaliteitenprincipe), een zeer positieve houding aangenomen. De krant behoort toe aan het ACW. Haar franstalige tegenhanger is La Cité (Brussel), spreekbuis en eigendom van de "Mouvement Ouvrier Chrétien" (MOC). Zij bezit helemaal niet de uitstraling in Wallonië, die Het Volk in Vlaanderen heeft weten te veroveren (2).

De krantengroep van Vers L'Avenir (Namen) bezit geen syndikale bipdingen, doch sluit nauw aan bij de christendemocratische richting van de PSC. Ook de kranten, die door deze groep gecontroleerd worden, ondergaan vanzelfsprekend sterk deze invloed. Dit is het geval met Le Courrier (Verviers) en L'Avenir du Luxembourg (Aarlen), die nochtans eertijds de spreekbuis was van de conservatieve politicus Pierre Nothomb. Ook de oude conservatieve Courrier de l'Escaut is nu praktisch volledig in handen van de groep-Vers L'Avenir.

Het gematigd vlaamsgezinde Het Belang van Limburg kan moeilijk een christendemocratische krant genoemd worden, omdat zij als dominetende regionale krant in Limburg de belangen van alle standen wenst

(2) La Cité is in felte de opvolgster van La Cité Nouvelle, gesticht in 1937 door Jean Bodart en verdwenen in 1940. Onder deze laatste titel verscheen zif opnieuw in 1944-47 als organ van de UDB (Union démocratique belge), de nieuwe partij die onmiddellijk na de Tweede Wereldoorlog een kort en roemloos bestaan kende. 
te verdedigen. Toch was de krant zeer lange jaren de spreekbuis van Mgr. P.J. Broeckx (1881-1968), die een zeer belangrijke rol speelde in de uitbouw van het ACW in Limburg.

\section{Vlaams-vooruitstrevende kranten.}

Alhoewel de hele pers, vooral sedert de jaren 1960, door de communautaire problemen in België beroerd wordt en alle vlaamstalige kranten met min of meer ijver de belangen van Vlaanderen trachten te verdedigen, zijn een aantal kranten traditioneel de spreekbuis geweest van de Vlaamse emancipatiestrijd.

Naast Het Laatste Nieuws van de familie Hoste, dat langs vrijzinnige kant onafgebroken voor de Vlaamse belangen in de bres sprong, is van katholieke zijde De Standaard zijn oorsprong essentieel verschuldigd aan de groei van de Vlaams Beweging. De grondleggers van deze krant Frans Van Cauwelaert, Dr. A. Van de Perre en A. Hendrix - wensten in de Belgische hoofdstad een invloedrijke spreekbuis op te richten voor de katholieke Vlaamse intelligentsia. Aan deze roeping is De Standaard steeds trouw gebleven, ook nadat de krant na de tweede Wereldoorlog uitgroeide tot de basiskrant van de zogezegde Standaard-groep. Tot deze groep behoren nu: De Standaard, Het Nieuwsblad, Het Handelsblad, De Gentenaar en De Landwacbt.

Alhoewel de Gazet van Antwerpen in 1891, het jaar van "Rerum Novarum », als christendemocratisch centenblad ontstond, kan men ze nog moeilijk als dusdanig aanzien, omdat zij een belangrijk deel van haar lezers werft in de Antwerpse zakenwereld. Vooral na de jaren 1960 is zij de nadruk gaan leggen op haar vlaamsgezinde houding, die wel eens kordater klinkt dan het proza van De Standaard. Opvallend is zelfs dat zij ruime aandacht besteedt aan de activiteiten van de Volksunie, die, in tegenstelling met het vooroorlogse VNV over geen eigen dagblad beschikt. In tegenstelling met De Standaard-groep, die op religieus en ethisch gebied graag zogezegde progressistische stellingen voorstaat, blijft de Gazet van Antwerpen op deze gebieden meer de getrouwe verdedigster van de traditionele christelijke waarden.

\section{Duitstalige pers.}

Het enige duitstalige dagblad, dat in België nog verschijnt, namelijk de Grenz-Echo (Eupen), behoort tot de katholieke opinierichting. Het is eerder conservatief gericht en verdedigt een loyaal-Belgisch standpunt. Wel is het sedert de laatste jaren, in het kader van de regionalisering van België, ten zeerste begaan met de toekomst van de Belgische Oostkantons, waarvan de krant de spreekbuis wenst te zijn. 


\section{De liberale opiniepers.}

Sedert het verdwijnen op 30 juni 1974 van Le Matin (Antwerpen) en La Flandre Libérale, de laatste spreekbuizen van de franstalige liberale bourgeoisie in Vlaanderen, beschikt de liberale opiniepers nog over zeven titels : 2 Vlaamse en 5 franstalige. Geen enkele van deze kranten fungeert als officieel orgaan van de Liberale partij (sedert 1961 de PVVPLP). OP sociaal-economisch vlak zijn zij alle behoudsgezind, in deze zin dat zij stelling nemen tegen de steeds sterkere druk van de overheid in de sociaal-economische sector. Ook al heeft het zogezegde neo-liberalisme op dit gebied wel compromissen aangegaan, toch blijven zij alle de nadruk leggen op het belang van het privaat initiatief in het ondernemingsleven.

Bij al deze kranten is het anti-clerikalisme, dat in de 19e - begin 20e eeuw een van de hoofdthema's uitmaakte, gaan verbleken. Op deze evolutie heeft de stichting van de PVV door O. Vanaudenhove op 8 oktober 1961 een niet geringe invloed uitgeoefend.

De twee liberale kranten met de hoogste oplage zijn Het Laatste Nieuws en La Dernière Heure, beide verschijnend te Brussel. Oorspronkelijk waren het radikale anti-clerikale bladen, doch het zijn nu overwegend algemene informatiekranten. Het Laatste Nieuws en zijn afhankelijke krant De Nieuwe Gazet dateren beide uit het einde van de $19 \mathrm{e}$ eeuw, doch weken tussen de beide wereldoorlogen nogal sterk van elkaar af wat hun houding tegenover de Vlaamse Beweging betreft. Terwijl Het Laatste Nieuws toen een vurige voorvechter werd van de realisatie van het Vlaamse minimumprogramma, stond De Nieuwe Gazet eerder afzijdig en vijandig. Deze toestand wijzigde zich echter na de Tweede Wereldoorlog, nu beide kranten een actieve rol spelen in de Vlaamse Beweging. De Nieuwe Gazet kan geen kopblad genoemd worden van Het Laatste Nieuws : zij is duidelijk afgestemd op de Antwerpse toestanden en is wellicht meer verpolitiekt dan Het Laatste Nieuws, dat met zijn hoge oplage een algemeen Vlaams volksblad wil zijn.

Langs franstalige zijde is La Dernière Heure de meest verspreide liberale krant, die meteen na de Tweede Wereldoorlog L'Avenir du Tournaisis kon opslorpen. Op het vlak van de advertentie is zij sedert 1946 verbonden met de katholieke conservatieve La Libre Belgique. Dit leidde tot economische interpenetratie van de twee kranten. Nadat eerst $\mathrm{La}$ Libre Belgique een belangrijke participatie in de aandelen van $\mathrm{La}$ Dernière Heure had verworven, gelukte er deze laatste in een meerderheidsparticipatie te bekomen in La Libre Belgique. La Dernière Heure is 
op het vlak van de communautaire betrekkingen de tegenhanger van Het Laatste Nieuws, waar zij het Brusselse en Waalse standpunt bijtreedt.

De liberale La Nouvelle Gazette (Charleroi) met haar plaatselijke edities - La Province te Bergen en Le Progrès te Namen - verloren sedert 1 maart 1968 hun economisch-financiële onafhankelijkheid, toen meer dan de helft van de aandelen in handen kwam van de S.A. Rossel. Zij blijven echter hun liberaal uithangbord bewaren en nemen, wat het communautair probleem betreft, een uitgesproken wallingantisch standpunt in.

\section{De socialistische pers.}

De socialistische pers, die over 7 titels beschikt, is, in tegenstelling met de katholieke en de liberale pers, veel meer partijgebonden. De socialistische kranten hangen ofwel rechtstreeks af van de BSP ofwel van de syndikaten. Daardoor vertonen deze kranten wel de neiging hun opdracht als opinievormers meer aan bod te laten komen dan hun meer algemene sociale functie, die in de eerste plaats ligt op het terrein van de algemene informatie. Buiten Le Peuple, die wil optreden als landelijke spreekbuis van de BSP zijn de andere kranten meer regionaal georiënteerd.

Rechtstreeks afhankelijk van de partij zijn: Le Peuple (Brussel), Vooruit (Gent), Volksgazet (Antwerpen), Le Monde du Travail (Luik) en Le Travail (Verviers). Dit blijkt onder meer uit sommige gemeenschappelijke hoofdartikels, meestal gepubliceerd door een vooraanstaand partijlid of de voorzitter van de partij, waarin de officiële stellingen van de partij over actuele vraagstukken worden verkondigd. Le Peuple met zijn plaatselijke edities - Le Monde $d u$ Travail en Le Travail - is in feite het officieel orgaan van de partij, terwijl de twee Vlaamse kranten - Vooruit en Volksgazet - eerder moeten doorgaan als de officiële organen van de Gentse en de Antwerpse socialistische federaties.

Naast de 5 officiële partijbladen verschijnen er in Wallonië nog $2 \mathrm{kran}$ ten, die nu overwegend toebehoren aan het syndikaat, FGTB. Zij kenden echter een eigen ontwikkeling die niet altijd trouw in het spoor liep van de BSP.

La Wallonie is eigendom van de federatie der metaalbewerkers van de FGTB der provincie Luik. Lang werd zij geleid door de socialistische wallingant André Renard (3) en zij is nog de spreekbuis van de «Mou-

(3) André Renard overleed plots op 20 juli 1962. Het directeurschap van de krant kwam in handen van Robert Lambion. 
vement populaire wallon », een linkse, wallingantische drukkingsgroep, gesticht in april 1961 door André Renard na de mislukte stakingen tegen de zogezegde Eenheidswet (4). De krant is aanhangster van het federalisme, vooral ook op economisch gebied, en nam op internationaal vlak herhaalde malen stelling tegen de Nato. Als dusdanig kwam zij meermaals in botsing met de officiële stellingen van de BSP.

Le Journal et Indépendance is in 1967 ontstaan uit een fusie tussen de oude Journal de Charleroi en de jongere Indépendance. Le Journal de Charleroi, gesticht als liberale krant in 1837 was in 1880 tot het socialisme overgegaan, doch behoorde tot 1967 toe aan de familie Bufquin des Essarts. Zij volgde dikwijls een zeer onafhankelijke socialistische koers. Indépendance (Charleroi), ontstaan uit de weerstand van tijdens de Tweede Wereldoorlog, was eerder linkssocialist georiënteerd (medewerking van F. Demany, minister van de weerstand in de na-oorlogse regering-Pierlot). Toen de twee kranten in 1967 fusioneerden onder de gemeenschappelijke titel Journal de Charleroi - Indépendance, gaf dit tijdelijk aanleiding tot de uitgave van een nieuwe titel; de plaatselijke editie te La Louvière werd immers genoemd: Journal du Centre-Indépendance. Deze afzonderlijke titel werd echter opgeheven en nu heet de krant Le Journal et Indépendance, maar draagt verschillende ondertitels volgens de plaatselijke edities (de Charleroi, du Centre, de l'Entre Sambre et Meuse, du Namurois, du Brabant Wallon). De krant is nu eigendom van de socialistische organisaties van Charleroi (de partij, het syndikaat en de socialistische mutualiteiten en coöperatieven).

De socialistische pers, en inzonderheid deze die rechtstreeks afhangt van de BSP heeft de laatste jaren met grote moeilijkheden te kampen. Zij dringt dan ook het sterkst aan op rechtstreekse overheidssteun om te kunnen voortbestaan. Alhoewel deze nu werd toegestaan, toch werden de kranten verplicht hun toevlucht te nemen tot materiële fusies. Op 17 juli 1974 besloten de socialistische partij-instanties Le Peuple en zijn twee kopbladen - Le Travail en Le Monde du Travail - van de Zandstraat te Brussel voortaan te laten drukken te Gosselies op de persen van Le Journal et Indépendance. De onderhandelingen tussen de twee Vlaamse socialistische kranten - Vooruit en Volksgazet - hebben voorlopig nog tot geen resultaat kunnen leiden.

(4) Deze wet voorzag, na de Congo-crisis, een verzwaring van de belastingen, maar tevens emstige bezuiniging op de overheldsultgaven, ook in de sociale sector, wat de socialistische oppositie in het harnas joeg tegen de CVP-liberale regering-EyskensLilar. 


\section{De «neutrale » pers.}

$\mathrm{Na}$ het verdwijnen van La Nation Belge in december 1956, bestaan er in België nog vier kranten, die zichzelf « neutrale » informatiekranten noemen, namelijk Le Soir, La Meuse, La Lanterne en Le Jour (Verviers). Opvallend is dat het allemaal franstalige kranten zijn.

La Nation Belge werd op het einde van de Eerste Wereldoorlog gesticht door de bekende publicist Fernand Neuray en ontwikkelde tussen de twee wereldoorlogen als «organe d'union nationale " een grote invloed. $\mathrm{Na}$ de Tweede Wereldoorlog trad er verval in en was er een ogenblik sprake van dat de krant zou worden overgenomen door de PSC. Uiteindelijk werd de krant eigendom van de financiële groep-graaf de Launoit, die op dat ogenblik reeds de hand had kunnen leggen op La Meuse van Luik en La Lanterne te Brussel. De krant bleek echter niet meer leefbaar en haar laatste nummer kwam van de pers op 31 december 1956.

De belangrijkste der zogenaamde «neutrale" kranten is Le Soir, oorspronkelijk een gratis advertentieblad. Zij noemt zich neutraal en wil dit bewijzen door de inschakeling van een «Tribune libre», waar regelmatig de prominenten van de drie traditionele partijen hun standpunt over actuele problemen kunnen verkondigen. Opvallend is dat deze 《Vrije Tribune » sedert 31 maart 1968 ook voor het FDF-RW werd open gesteld, doch niet voor de Volksunie. De krant heeft trouwens nooit een werkelijk neutraal standpunt gehuldigd en nam regelmatig scherp stelling in de grote problemen van de dag: vóór de Eerste Wereldoorlog pleitte zij voor de overname door België van CongoVrijstaat (1908) en voor het verplicht lager onderwijs (Wet van 19 mei 1914); tussen de twee wereldoorlogen nam zij stelling tegen het VNV en het Rexisme; na de Tweede Wereldoorlog kantte zij zich tegen de terugkeer van koning Leopold III. Daarbij is zij doorlopend anti-flamingant, onder meer in het probleem van de Brusselse randgemeenten, waar zij de stellingen van het FDF verdedigt.

De oude Luikse krant La Meuse, opklimmend tot 1856, geeft zich uit als «quotidien belge d'information illustré ». Oorspronkelijk was het een liberale krant, die zich reeds sedert 1899 «neutraal » heeft genoemd. Sedert 1944 bezat zij te Brussel de beeldkrant La Lanterne. In 1948 werden de twee kranten opgekocht door graaf de Launoit, die ze in oktober 1966 op zijn beurt overmaakte aan de groep Rossel ( $L e$ Soir), zodat deze groep op dit ogenblik drie van de vier zogezegde « neutrale » kranten in zijn bezit heeft. Evenmin als Le Soir hebben La Meuse en La Lanterne een werkelijk neutraal standpunt gehuldigd. 
Zij namen bijvoorbeeld scherp stelling tegen de beweging van André Renard in 1961-62 tijdens de staking tegen de Eenheidswet; verder volgen zij op internationaal vlak eerder een rechtse koers.

Le Jour van Verviers, de vierde krant die zich als « neutraal 》 voorstelt, houdt zich wellicht nog het best aan haar opdracht. Als « journal quotidien d'information » hecht zij vooral belang aan de economische streekbelangen.

\section{De oplage van de Belgische pers per opinierichting.}

$\mathrm{Na}$ de afschaffing van de zegelbelasting op de Belgische pers door de wet van 26 mei 1848 (5) kennen wij de oplage van deze pers slechts bij benadering. De zeer precies gekende cijfers uit de periode van de zegelbelasting, toen alleen de rijke cijnskiezers op de krant abonneerden, ziji trouwens niet vergelijkbaar met de oplage sedert de late $19 \mathrm{e}$ eeuw, toen de krant een goedkoop massaproduct werd. Tussen 1830 en 1848 groeide de oplage van de Belgische pers van ongeveer 22.000 tot ongeveer 50.000 nummers per dag. Op dit ogenblik mag aanvaard worden dat, trots de stagnatie die zich voordoet, de Belgische pers nog steeds een dagelijkse oplage van boven de 2 miljoen bezit (6).

Dat wij nu met een zekere benadering de werkelijke oplage van de Belgische pers kunnen bepalen, danken wij aan een aantal controlemiddelen, waaraan een groot gedeelte van de Belgische pers zich wel wil onderwerpen. Sedert 1951 werd de DEVEA (Dienst voor publicitaire verspreidingsanalyse) of OFADI (Office d'Analyse de la Diffusion Publicitaire) opgericht. Deze dienst ontstond op initiatief van drie groepen, die om beurt het vootzitterschap waarnemen: De Belgische Bond van Adverteerders, de Publiciteitsagenten en de Persorganen. DEVEA/ OFADI stelde tot 1971 de oplage vast van een aantal kranten, die zich aan de controle van deze organisatie wilden onderwerpen. Op 12 mei 1971 versmolt DEVEA/OFADI met het «Belgisch Studiecentrum voor Reclamemedia » (Centre d'Etude belge des supports de publicité) onder de benaming «Centrum voor Informaties over de media " (CIM).

(5) Cf Th. LUYKX, Ben halve eerno zegelbelasting op de Belgische pers (september 1797-mel 1848), in : Med. Kon. V1. Acad. voor Wet., Lett. en Schone Kunsten, Brussel, 1956 ; De verhouding van de Vlaamse en franstallge pers in Belgie rond 1844, in : Hand. Kon. Zuidned. Mif voor Taal-Lett. en Geschiedenis, dl. XXII, 1968, pp. 305-318.

(6) De pers zelf heeft vanzelfsprekend de neiging has oplage te overdrijven. Dit is dan ook de oorzak dat de Unesco (L'Information a travers le Monde, 1956), op basis van de mededelingen van de krantendirecteurs, een oplagecljfer van 3.343 .000 opgaf, wat erg overdreven is. Wij mogen wel aanvoorden dat de oplage in 1975 lager ligt dan in 1955, doch het staat vast dat de Belgische pers geen mllioen lezers in 20 falt tijd verloor. 
De oplage van de kranten, die zich tot 1971 door DEVEA en sindsdien door CIM laten controleren, kan wel als volledig vertrouwbaar aangezien worden.

Het is een opvallend verschijnsel dat praktisch heel de nederlandstalige pers zich aan de oplagecontrole van CIM onderwerpt, terwijl heel wat franstalige kranten dit weigeren te doen. Voor deze laatste kranten beschikken wij enkel maar over een onrechtstreekse controle langs Belga, dat zijn abonnementsprijs afhankelijk maakt van het door de directeurs van deze kranten medegedeeld oplagecijfer. De ongecontroleerde kranten hebben er wel voordeel bij hun oplagecijfers te overdrijven om alzo de adverteerders te misleiden, doch anderzijds moeten zij daardoor het Belga-abonnement duurder betalen. Alhoewel wij mogen aanvaarden dat de ongecontroleerde kranten hun oplagecijfer naar de hoge kant afronden, toch heeft de verklaring van de uitgever een zekere waarde. Ook moet onderstreept worden dat de verschillende bestaande krantengroepen de laatste jaren alleen de oplage mededelen voor de hele groep van kranten en niet voor de afzonderlijke krantentitels, die tot de groep behoren.

\section{Oplage van de katholieke pers.}

Van de 20 titels van de katholieke pers behoren er niet minder dan 16 tot 5 verschillende krantengroepen: drie in Vlaanderen en twee in Wallonië. De drie Vlaamse krantengroepen laten alle hun oplage door CIM controleren, terwijl slechts één van de twee franstalige krantengroepen dit goed voorbeeld volgt. Van de 4 overige afzonderlijke kranten weigeren de drie franstalige zich aan een controle te onderwerpen, terwijl het enige Vlaamse dit wel doet.

De drie Vlaamse krantengroepen zijn: 1. De Standaard-groep (De Standaard, Het Nieuwsblad, De Gentenaar, De Landwacht en Het Handelsblad) met een gecontroleerde oplage van 335.839 in 1969 en 340.148 in 1973 ; 2. de groep van Het Volk ( + De Nieuwe Gids) met een gecontroleerde oplage van 216.351 in 1966 en 222.508 in 1973; 3. de groep van de Gazet van Antwerpen ( + de Gazet van Mechelen) met een gecontroleerde oplage van 174.786 in 1965 en 210.823 in 1973.

De twee franstalige krantengroepen zijn: 1 . de groep van Vers l'Avenir ( + L'Avenir du Luxembourg, Le Courrier en Le Courrier de l'Escaut), die een gecontroleerde oplage bezat van 87.657 in 1967 en van 113.327 in 1973 ; 2. de groep van Le Rappel (+ L'Echo du Centre en Journal de Mons), die echter zijn oplage niet laat controleren. De uitgever, die gedurende enkele jaren volhield dat de oplage van zijn krantengroep 70.500 nummers bedroeg, daalde in 1973 af tot 69.000 . 
Van de 4 afzonderlijke katholieke kranten laat alleen Het Belang van Limburg zijn oplage door CIM controleren. Deze regionaal -georiënteerde krant is trouwens nog steeds in volle expansie. Haar oplage in 1966 bedroeg 55.661 nummers en in 1973 was dit reeds opgeklommen tot 76.284. La Libre Belgique, waarvan de uitgever in 1969 nog verklaarde dat de oplage 170.000 bedroeg, geeft sedert 1970 onveranderlijk het oplagecijfer van 160.000. De christendemocratische La Cité vermeldt onveranderlijk sedert 1969 het oplagecijfer van 40.000, terwijl de katholieke Grenz-Ecbo ook onveranderlijk sedert jaren verklaart dat zij een oplage van 15.000 bezit.

Op basis van al deze gegevens komt men voor het jaar 1973 tot de slotberekening dat de vlaamstalige pers een oplage bezit van 849.783 , de franstalige een oplage van 366.827 en de duitstalige van 15.000 . Wij mogen echter gerust aannemen dat de franstalige en de duitstalige enigszins haar oplage overdrijft.

\section{De oplage van de liberale pers.}

De 7 titels van de liberale pers behoren allen tot 3 krantengroepen, waarvan er 2 hun oplage door CIM laten controleren. 1. Het Laatste Nieuws ( + De Nieuwe Gazet) bezat in 1964 een gecontroleerde oplage van 296.558 en kon zijn oplage nog opdrijven tot 307.959 in 1973 ; 2. La Nouvelle Gazette ( + La Province en Le Progrès), waarvan echter de meerderheid van de aandelen sedert 1 maart 1968 in de handen berusten van SA Rossel (Le Soir), laat ook haar oplage controleren, waaruit trouwens blijkt dat zij tot de weinige franstalige kranten behoort, die met betrekking tot de oplage winst boekt. Haar oplage evolueerde immers van 59.960 in 1965 tot 72.834 in 1973 ; 3. La Dernière Heure (+ L'Avenir du Tournaisis) laat haar oplage niet controleren. De uitgever verklaart elk jaar opnieuw dat de oplage van zijn krantengroep 160.000 nummers bedraagt.

Op basis van deze gegevens komt men voor het jaar 1973 tot de slot\$om dat de vlaamstalige liberale pers een oplage van 307.989 bezit, de franstalige een oplage van 232.834. Andermaal moet echter rekening gehouden worden met het feit dat het oplagecijfer van de franstalige pers enigszins overdreven kan zijn.

\section{De oplage van de socialistische pers.}

Van de 7 titels van de socialistische pers maken er 3 deel uit van een krantengroep, namelijk van Le Peuple, die echter zijn oplage niet laat controleren. Van de overige 4 afzonderlijke kranten lieten alleen de vlaamse zich controleren, doch slechts tot het jaar 1971, terwijl de franstalige ook niet in hun oplage-papieren laten kijken. Men mag dus bij 
voorbaat aanvaarden, dat de meegedeelde oplage, die al niet groot is, nog erg overdreven is.

De krantengroep van Le Peuple (+ Le Monde du Travail en Le Travail) beweerden in 1960 dat de gezamenlijke oplage voor de 3 kranten nog ongeveer 130.000 bedroeg, doch naar de eigen verklaring van de uitgever was dit oplagecijfer in 1973 gedaald tot 60.000. De twee Vlaamse socialistische kranten, Vooruit en Volksgazet, lieten hun oplage controleren tot in het jaar 1971 en vermelden sedertdien steeds onveranderd hetzelfde cijfer. De oplage van Vooruit daalde van 41.415 in 1959 tot 32.639 in 1971; deze van Volksgazet daalde van 111.753 in 1959 tot 78.034 in 1971. De twee franstalige afzonderlijke kranten laten zich helemal niet controleren, zodat wij ons hier moeten tevreden houden met een verklaring van de uitgever. Le Journal et Indépendance geeft onveranderlijk het oplagecijfer 70.000 aan, terwijl $\mathrm{La}$ Wallonie, steeds volgens de uitgever, zijn oplage zag slinken van 50.000 in 1969 tot 40.000 in 1973.

Op basis van deze gegevens zou de Vlaamse socialistische pers nog een oplage bezitten van 110.673 en de franstalige van 170.000 . Het staat echter vast dat deze oplagecijfers erg overdreven zijn.

4. De oplage van de zogezegde neutrale pers.

Drie van de vier zogezegde neutrale kranten behoren toe aan de SA Rossel, die Le Soir uitgeeft en sedert oktober 1966 ook La Meuse (Luik) en La Lanterne kon bemachtigen.

De groep van Le Soir ( + La Meuse en La Lanterne) laat haar oplage door CIM controleren en hieruit blijkt dat hij de laatste jaren ernstige verliezen boekt. De oplage van Le Soir zelf evolueerde immers van 305.041 in 1957 tot 270.709 in 1972 . De afhankelijke kranten - La Meuse en La Lanterne - schijnen echter beter stand te houden. De oplage van de twee kranten samen evolueerde van 182.819 in 1969 tot 186.498 in 1973.

De neutrale krant van Verviets, Le Jour, laat haar oplage niet controleren en de uitgever verklaart jaarlijks dat $\mathrm{zij}$ een oplage van 22.000 bezit.

Op basis van deze gegevens zou de Belgische zogezegde "neutrale» pers, die alleen franstalig is, een oplage van 479.205 bezitten.

5. Oplage van de communistische dagbladpers.

Nadat De Rode Vaan op 1 januari 1959 en Le Drapeau Rouge op 1 oktober 1966 van dagblad tot weekblad waren overgeschakeld, bezat de communistische partij tijdelijk geen dagblad meer. Op 2 januari 1974 schakelde Le Drapeau Rouge opnieuw over van weekblad op dagblad, 
zodat sedertdien de communistische partij opnieuw over een dagelijks partij-orgaan beschikt. De krant laat haar oplage niet door CIM controleren en wij moeten ons dus tevreden houden met de verklaring van de uitgever dat zij op 15.000 exemplaren op de markt wordt gebracht.

\section{Besluit.}

Het staat vast dat de oplage van de Belgische pers, die op basis van de bovenvermelde inlichtingen nagenoeg 2,5 miljoen zou bedragen, zeker met een paar honderdduizend moet gereduceerd worden. Dit is te wijten aan het feit dat een groot gedeelte van de franstalige pers geen oplagecontrole toestaat en anderzijds dat ook de vlaamstalige socialistische pers haar oplage overdrijft.

Op basis van de bovengenoemde oplagecijfers en abstractie gemaakt van de plausibele overdrijvingen, zou de Belgische pers in 1973-74 per opinierichting er als volgt uit zien :

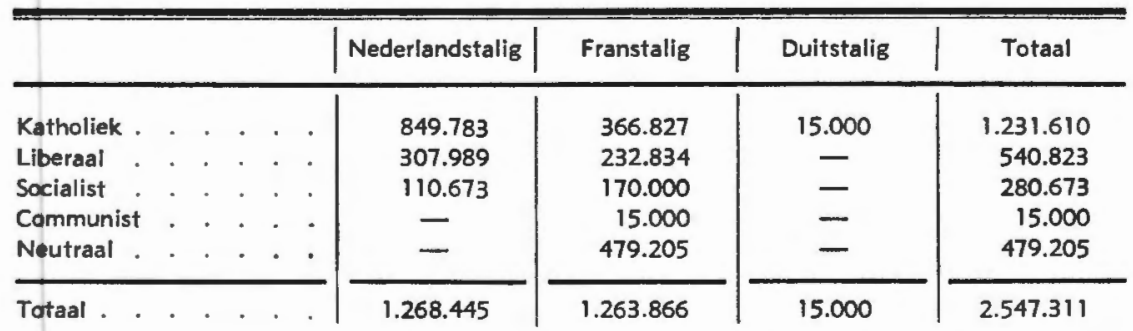

Uitgedrukt in procenten van de oplage van de gehele Belgische pers, verloopt de evolutie van de oplage per opinierichting in de jaren 19581973 als volgt :

Nederlandstalige pers (in procenten der totale Belgische oplage).

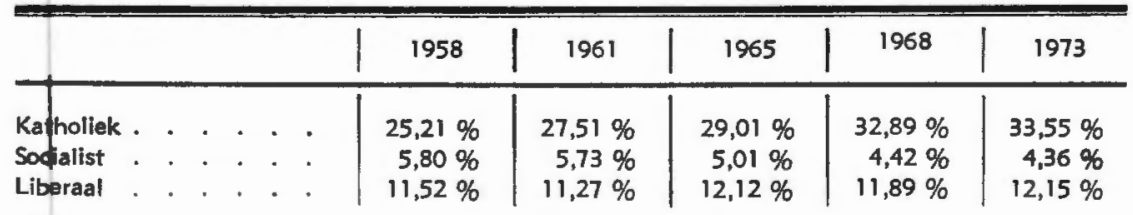

Voor de franstalige pers moet men, in tegenstelling met de nederlandstalige, rekening houden met een zogezegde neutrale pers, die in Viqanderen niet bestaat.

Wat de franstalige opiniepers betreft, stelt men, wat de oplage betreft, nagenoeg dezelfde evolutie vast als in Vlaanderen. 
Franstalige pers (in procenten der totale Belgische oplage).

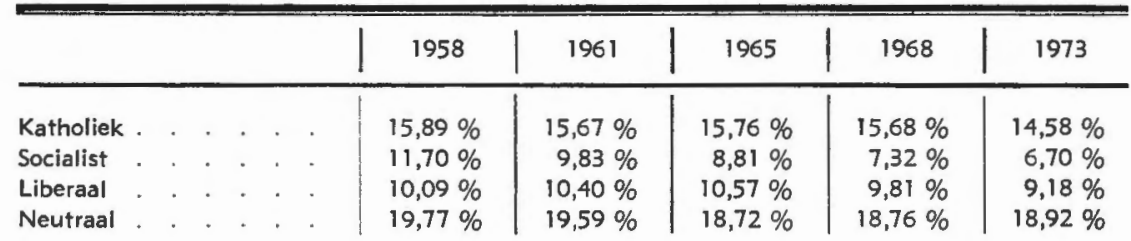

\section{De verhouding krantenlezers-kiezers.}

Er bestaat in België een duidelijke wanverhouding tussen het aantal lezers van kranten en het aantal stemmen, dat op politieke partijen bij verkiezingen wordt uitgebracht (7).

De toestand is echter wel verschillend geworden na 1961, toen het partijleven zelf in België ernstige wijzigingen onderging.

\section{De toestand tot 1961.}

Toestand in 1958.

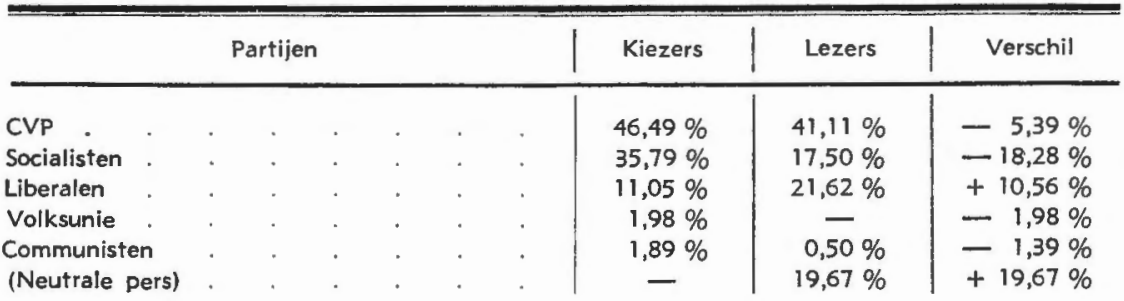

Toestand in 1961.

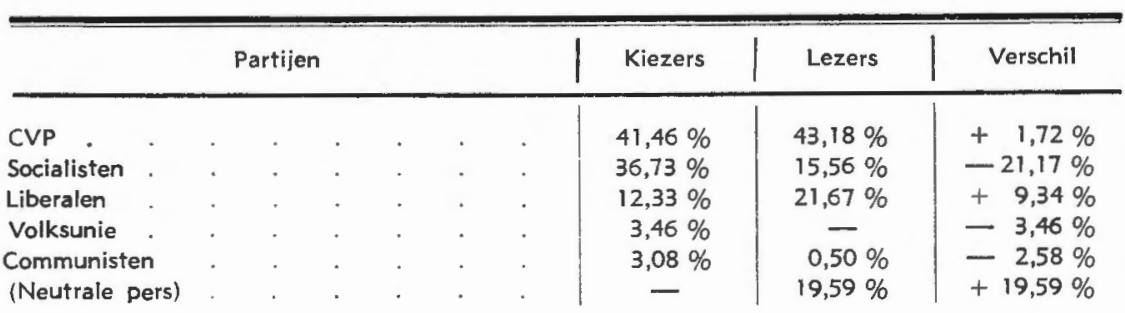

(7) Wat het aantal kiezers betreft, steunden wij ons vanzelfsprekend op de officiele verkiezingsuitslagen. Voor het aantal krantenlezers konden wij te raden gaan bif het tijdschrift De Pers-La Presse. Het is echter duidelijk dat de statistieken betreffende de kiezers precieser zijn dan deze betreffende de krantenlezers. Voor het uitrekenen van de verhouding kiezers-krantenlezers steunden wij ons op de licentieverhandeling van JULIEN HERREMANS, Discrepantie tussen kiezers en dagbladlezers sinds 1958 (Gent, academiejaar 1970-1971). Voor de jaren 1971 en 1974 werden de berekeningen door ons zelf gemaakt. 
Uit deze verhoudingen mag afgeleid worden dat tot 1961 het aantal lezers van katholieke kranten ongeveer samenviel met het aantal CVPstemmers. Men merke echter op dat het antal stemmers voor de CVP verminderde, terwijl het aantal lezers van katholieke kranten toenam. Het aantal lezers van liberale kranten overtrof in grote mate het aantal liberale kiezers, terwijl het aantal lezers van socialistische kranten ver beneden het aantal kiezers ligt, dat voor de BSP stemt. Men zou er dok uit kunnen afleiden dat de lezers van neutrale kranten meestal niet stemmen voor de CVP.

\section{De toestand in de jaren 1961-1974.}

$\mathrm{Na} 1961$ onderging het partijwezen in België betrekkelijk ernstige omvormingen, zodat ook het kiezerscorps, dat tot dan toe zeer stabiel was, zich wijzigde. Ingevolge de koerswijziging van de liberale partij, die haar anti-clericalisme liet varen en de nieuwe naam kreeg van Partij voor Vrijheid en Vooruitgang (PVV) lokte de partij meer kiezers aan. Daarbij wonnen de federalistische partijen - de Volksunie in Vlaanderen en het Rassemblement Wallon in Wallonië - veld, terwijl ook de Brusselse francofone taalpartij, het Front des Francophones (FDF) haar intrede deed in het parlement. Van dit alles werden de twee grote partijen - de CVP en de BSP — slachtoffer.

Toestand in 1965.

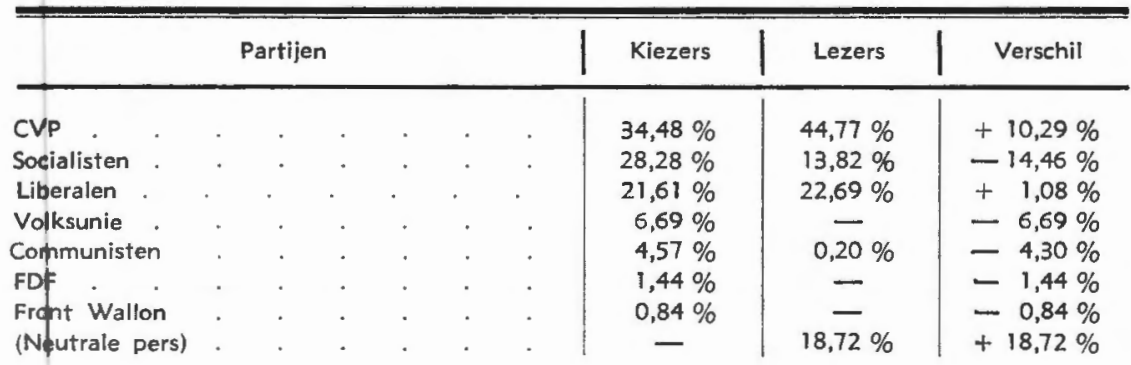

Hieruit blijkt vooreerst dat de krantenlezers de zwenking van de palitieke verschuivingen niet volgden. De krantenlezers bleken stabieler te zijn dan de kiezers. Het aantal liberale krantenlezers benadert nu het aaptal kiezers, doch dit was niet te wijten aan de vermindering van dq liberale lezers, maar aan de toename van de PVV-stemmers. De 
afbraak van de socialistische pers blijkt echter onafgebroken verder te gaan (8).

Toestand in 1968.

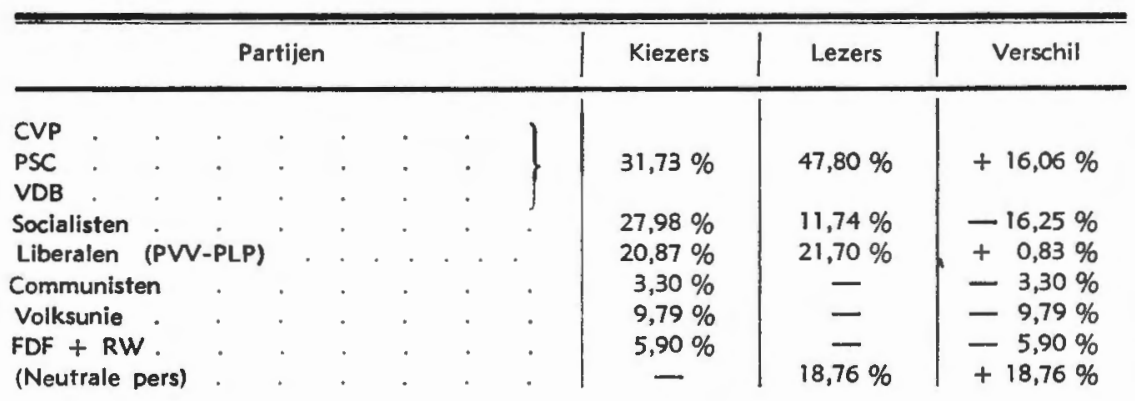

Wat de katholieke pers betreft heeft het verschijnsel van 1965 zich nog geaccentueerd : het aantal CVP-stemmers daalt nog, doch het aantal lezers van katholieke kranten neemt steeds toe. Zowel het aantal kiezers van de PVV als dat van de lezers van liberale kranten zijn iets verminderd, doch de verhouding tussen de twee is zeer evenwichtig. De BSP heeft een klein aantal kiezers verloren, doch de oplage van de socialistische pers blijft in veel grotere mate dalen.

Toestand in 1971.

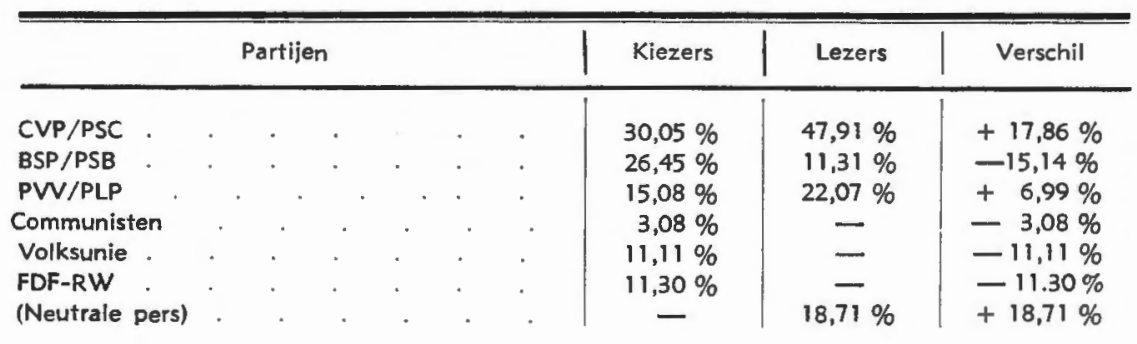

De CVP/PSC-kiezers zijn nog verminderd, doch de katholieke pers heeft haar oplage nog kunnen vergroten sedert 1968. Het aantal socia-

(8) Cf M. BAUWENS, De Partijkrant, een noodlottige formule, in : Tijdschrift voor Sociale Wetenschappen, jg. XV, 1970, pp. 42-46, - Een onderzoek, uitgevoerd door J. Van Buggenhout bif fongens tussen 15 en 20 jaar, wees uit dat $81 \%$ van de jeugdige lezers de voorkeur geeft aan een niet uitgesproken partijkrant. Cf J. VAN BUGGENHOUT, Een enquete over de dagbladpers bij jongeren, in : Socialistische Standpunten, 1971, nr 2 ; Zle ook: J. VERHELST, De socialisten moeten een goede krant maken die de legers willen kopen, in : De Bond, 25 september 1970. 
listische kiezers is lichtjes verminderd en haar pers, die reeds op een 1kagtepunt stond in 1968, heeft nog lezers verloren. De PVV/PLP kiezers kennen een ernstige achteruitgang, zodat er opnieuw een verschil optreedt tussen het aantal kiezers en lezers van liberale kranten: het antal lezers heeft weer in ernstige mate het aantal kiezers overtroffen, zij het dan ook niet in zo grote mate als in de jaren 1958-1961, vóór de hervorming van de liberale partij.

Toestand in 1974.

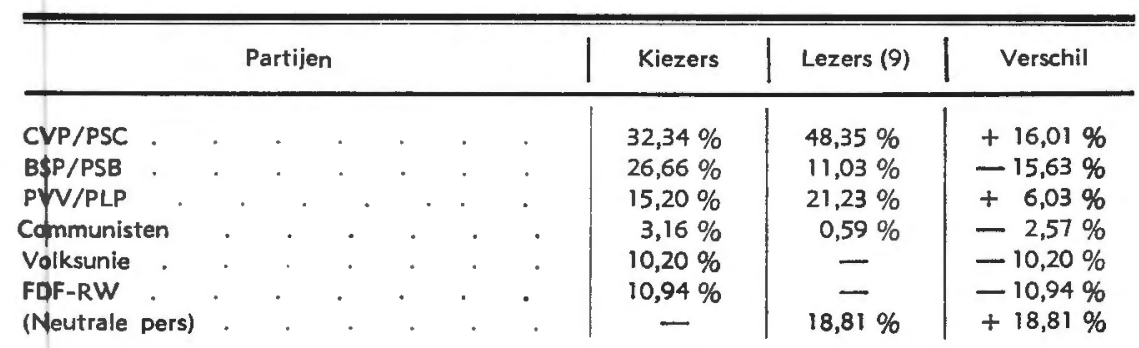

De CVP/PSC hebben een ernstige winst geboekt, die iets groter is dan de aangroei van de katholieke krantenlezers, doch dit neemt niet weg dat het aantal lezers van katholieke kranten nog steeds toeneemt. De socialisten hebben op electoraal vlak een kleine winst geboekt, maar het aantal lezers van socialistische kranten daalt nog steeds voort. Wat de PVV/PLP betreft werd, zowel wat betreft het aantal kiezers als het aantal krantenlezers, nagenoeg het status quo van 1971 bewaard.

3. De verhouding van de nederlandstalige en franstalige pers tegenover bat Vlaamse en franstalige kiezerscorps.

Voor de verhouding kiezers-lezers kunnen, zoals boven blijkt, voor de situatie in het land wel nagenoeg preciese gegevens worden meegedeeld. Dit wordt echter onmogelijk, indien men het Vlaamse en franstalige kiezerscorps wil vergelijken met de kiezers in de verschillende landsgedeelten. De oorzaak hiervan is gelegen in het arrondissement Brussel, whar men wel kan uitmaken hoeveel Vlaamse en franstalige kandidaten werden gekozen, maar niet hoeveel nederlandssprekenden en fransprekenden aan de verkiezingen deelnamen.

(9) Wif hebben voor het aantal lezers geen rekening meer gehouden met de drie franstalige kranten in Vlaanderen - La Métropole, Le Matin en La Flandre Libérale - die op 30 juni 1974 definitlef verdwenen. 
Toch loont het de moeite de evolutie vast te stellen van de percentages die de verschillende opinierichtingen vertegenwoordigen in de nederlands- en franstalige pers.

De nederlandstalige pers

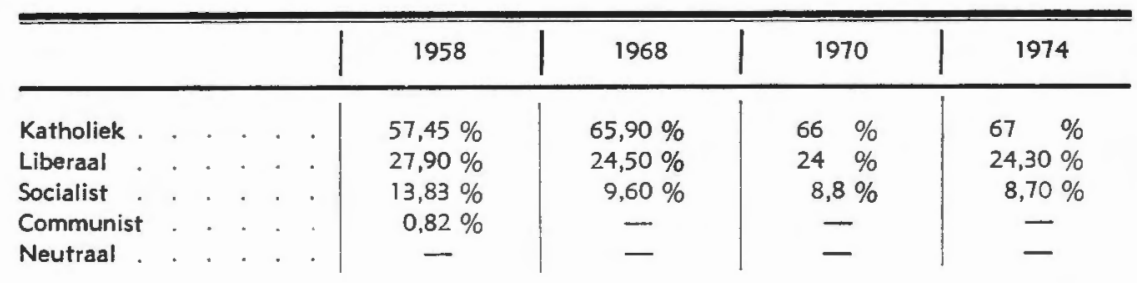

De nederlandstalige pers in Vlaanderen is dus overwegend katholiek en won in 16 jaar zelfs nagenoeg $10 \%$ bij van de totale oplage van de nederlandstalige pers in Vlaanderen. De liberale pers in Vlaanderen cirkelt rond de $24 \%$, terwijl de socialistische pers geen $10 \%$ van het aantal lezers in Vlaanderen bereikt.

\section{De franstalige pers}

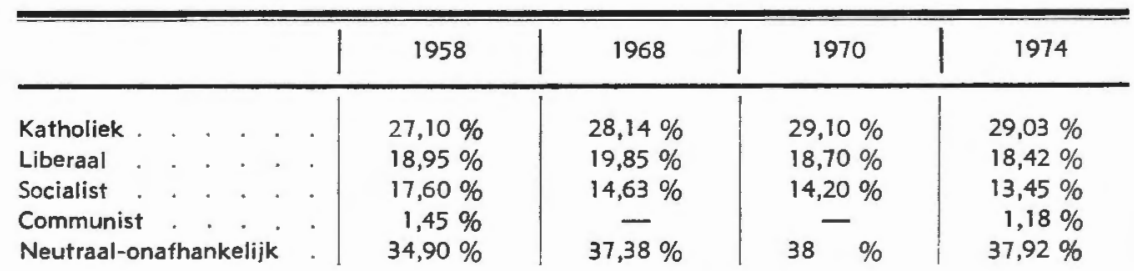

Bij de franstalige pers is de situatie enigszins verwrongen, omdat zulk groot procent lezers zogezegde neutrale kranten leest. Vooral socialistische kiezers moeten deze neutrale pers lezen, want het aantal socialistische kiezers overtreft in zeer sterke mate het aantal lezers van socialistische kranten.

\section{Nabeschouwing.}

De geschreven pers wordt de laatste jaren in alle democratische landen, ook in België, met een aantal problemen geconfronteerd, die in hoofdzaak verband houden met de verdere industrialisering van de krantenonderneming en de steeds toenemende concurrentie van de audiovisuele media. 
In de meeste landen wordt vooral de uitgesproken politieke pers hiervan het eerste slachtoffer. Dit kan echter niet beweerd worden voor het geheel van de Belgische pers en zeker niet voor de Vlaamse pers. Zowel de katholieke als de liberale kranten houden in het algemeen goed stand, ook al wordt hun expansie geremd door de twee bovenvermelde factoren.

Voor de socialistische pers is dit echter helemaal niet het geval. Onze berekeningen steunden op een zogezegde oplage van ongeveer 280.000 in 1973 ; dit op basis van de cijfers, die door de socialistische pers zelt wordt medegedeeld. In werkelijkheid zou deze oplage slechts ongeveer 210.000 bedragen. Rond de oorzaken van dit verval kan ongetwijfeld geredetwist worden. Feit blijft dat zij, in tegenstelling met de katholieke en de liberale pers, veel meer partij-gebonden is. Dat deze oorzaak zonder twijfel meespeelt, blijkt duidelijk uit de houding van Vooruit, die enkele maanden geleden maatregelen trof om deze partijgebondenheid te verdoezelen.

Om te maken dat bepaalde opinierichtingen, inzonderheid de socialistische, langs de dagbladpers nog voldoende aan het woord zou komen, werd de laatste jaren de « rechtstreekse overheidssteun » aan de kranten als de enige mogelijke remedie aangezien. Ook de krantenondernemingen, die financieel gezond zijn, hebben deze overheidssteun aanvaard, echter bij wijze van «compensatie » voor de geleden schade, inzonderheid vanwege de TV. Dat de Overheid in 1958 ertoe bijdroeg om de dagbladpers van haar zondagsnummer te beroven, terwijl de TV, gespijzigd door overheidsgelden, de informatie op Zondag verder bleef verzorgen, lijkt wel op deloyale concurrentie. Welke invloed deze betwistbare « rechtstreekse overheidssteun » op de politieke pers zal uitoefenen, moet de toekomst nog uitwijzen.

\section{Summary: Opinion trends in the Belgian newspapers.}

From the outset the Belgian press has been a political press. The catbolic and liberal newspapers, however, have never been tightly linked to the corresponding political parties, whereas the socialist and communist newspapers depend officially from their respective political party so that they can be considered as real party-papers.

Of the 39 Belgian newspapers 20 can be defined as catbolic, 7 as liberal, 7 as socialist and 1 as communist; 4 newspapers call themselves "neptral", but on several political occasions they beve nevertbeless taken up position. Among these 39 newspapers only 19 can be considered as independent $》$ : of the 20 catholic newspapers 16 belong to 5 dif- 
ferent newspaper chains; 7 of the liberal dailies are owned by only 3 newspaper groups; 3 of the 7 socialist papers belong to the same chain and 3 of the so-called "neutral » dailies are publisbed by only one group.

From the circulation figures of the Flemish press it emerges that the catbolic and liberal newspapers make some progress, while the socialist dailies are constantly regressing. The total circulation of the Frenchspeaking newspapers is slightly receding, but bere again the socialist newspapers are the big losers. It should be noticed that only the circulation figures of the Flemish newspapers are officially ascertained, whereas the major part of the French-speaking newspapers do not allow such an official control.

From this it is clear that in Belgium there exists a real disproportion between the number of readers of political opinionnewspapers and the voters for the corresponding political parties. For the moment the number of readers of catbolic newspapers surpasses the amount of voters for the CVP-PSC-party in an considerable way. This also applies to the liberal press, where the amount of readers outnumbers the voters for the PVV-PLP-party. On the other hand, the number of readers of socialist newspapers even does not amount to balf of the numbers of voters for the BSP-PSB-party. 